This PDF is a selection from a published volume from the National Bureau of Economic Research

Volume Title: Measuring Economic Sustainability and Progress

Volume Author/Editor: Dale W. Jorgenson, J. Steven Landefeld, and Paul Schreyer, editors

Volume Publisher: University of Chicago Press

Volume ISBN: 0-226-12133-X (cloth); 978-0-226-12133-8

(cloth); 978-0-226-12147-5 (eISBN)

Volume URL: http://www.nber.org/books/jorg12-1

Conference Date: August 6-8, 2012

Publication Date: September 2014

Chapter Title: Trends in the Distribution of Household Income, 1979-2010

Chapter Author(s): Edward Harris, Frank Sammartino

Chapter URL: http://www.nber.org/chapters/c12827

Chapter pages in book: (p. 181 - 211) 


\title{
Trends in the Distribution of Household Income, 1979-2010
}

\author{
Edward Harris and Frank Sammartino
}

\subsection{Introduction}

Numerous studies have found that the distribution of income in the United States has become increasingly unequal - in particular, the share of income accruing to the highest-income households has increased, whereas the share accruing to other households has declined. That finding is robust across numerous methodologies, income definitions, and data sources. Other developed economies have experienced a similar long-term trend toward greater inequality in household income (OECD 2008).

The primary source for information on the income distribution in the United States is the Annual Social and Economic Supplement to the Census Bureau's Current Population Survey (CPS). That survey captures the demographic characteristics and income for a large sample of households. As computed by the Census Bureau, the Gini index for household money income - a before-tax income measure that includes some government transfers - rose from 0.397 in 1967 to 0.469 in 2010, though some of that increase reflects changes in data collection methodology (Jones and Weinberg 2000; DeNavas-Walt, Proctor, and Smith 2010; Burkhauser et al. 2008).

In an influential paper, Thomas Piketty and Emmanuel Saez used data from tax returns to examine market income inequality in the United States over almost a century (Piketty and Saez 2003). They found that income con-

Edward Harris is principal analyst at the Congressional Budget Office. Frank Sammartino is assistant director for tax analysis at the Congressional Budget Office.

The authors would like to thank Edward Wolff, Dale Jorgenson, Alice Henriques, and Paul Schreyer for their helpful comments. The views presented here are those of the authors and do not necessarily reflect those of the Congressional Budget Office. For acknowledgments, sources of research support, and disclosure of the authors' material financial relationships, if any, please see http://www.nber.org/chapters/c12827.ack. 
centration dropped dramatically following World War I and World War II, remained roughly unchanged for the next few decades, and then rose starting in 1975, reaching pre-World War I levels by 2000. Increases within the top percentile of the income distribution were especially dramatic.

Each of those data sources has strengths and limitations. ${ }^{1}$ The key advantage of tax return data is richness at the top of the income distribution, where much of the change in the income distribution has occurred, owing to very high sampling rates among high-income taxpayers. Tax return data are not subject to the traditional forms of measurement error found in household surveys, though taxpayers certainly face incentives to report their income in a way that minimizes their tax liability. Tax return data, however, is of limited usefulness in describing the bottom of the income distribution: it lacks information on individuals who do not file a federal tax return, does not report income from many government cash transfer programs, and has no information about the receipt of in-kind government transfers and benefits. In contrast, the CPS better represents the whole population and generally captures income from a broader array of sources, although income from government transfer programs tends to be underreported. However, the CPS is weaker for describing the top of the income distribution, as it does not oversample high-income households and topcodes their incomes. The CPS also does not report capital gains income, significantly underreports other income from capital, and lacks information on deductions and adjustments necessary to accurately compute income taxes.

This chapter presents estimates of the distribution of household income in the United States derived from a statistical combination of data from the Current Population Survey and from samples of income tax returns. This combined series overcomes some limitations of estimates produced from either the CPS or the income tax data alone: it covers the full population while maintaining the richness at the top of the income distribution, and can yield comprehensive estimates of the effect of the tax and transfer system on the full income distribution. The chapter focuses on the inequality of income after taxes and transfers, and decomposes the effects of the market income distribution, the tax system, and the transfer system on the inequality of household income after government transfers and federal taxes. ${ }^{2}$

\subsection{Methodology}

\subsubsection{Data}

This analysis draws its information on income from two primary sources. The core data come from the Statistics of Income (SOI), a nationally repre-

1. For a more complete description of the advantages and disadvantages of income statistics derived from tax returns and from household surveys, see Atkinson, Piketty, and Saez (2011).

2. These estimates have also been presented in Congressional Budget Office papers (Congressional Budget Office 2011, 2012). 
sentative sample of individual income tax returns collected by the Internal Revenue Service. ${ }^{3}$ The number of returns sampled has grown over the time period studied, ranging from roughly 90,000 in some of the early years to more than 300,000 in the later years. In the later years of the analysis, those tax returns are matched to certain information returns, such as W-2 and 1099 forms. Information returns provide data not available on the tax returns, such as the split of wages between spouses in married couples, contributions to deferred compensation plans, and Social Security benefits for filers with income below the level at which they are required to report those benefits.

Tax return information is supplemented with data from the Annual Social and Economic Supplement to the Census Bureau's Current Population Survey, which contains survey data on the demographic characteristics and income of a large sample of households. The two sources are combined by statistically matching each SOI record to a corresponding CPS record on the basis of demographic characteristics and income. Each pairing resulted in a new record that takes on some characteristics of the CPS record and some characteristics of the SOI record. ${ }^{4}$

The first step in the matching process is to align the unit of analysis by constructing tax-filing units from CPS households. A tax-filing unit is a single person or a married couple plus their dependents, and often differs from a CPS family. To construct tax units, household heads and their spouses are considered to be primary filing units. We apply tax rules to see if other members of the household can be claimed as dependents (in order to be a dependent, a person must meet certain age, relationship, and income requirements). We assign people who meet the dependent tests as dependents while those not meeting the test we classify as separate tax units. In cases where multiple people could potentially claim a dependent, we assume that the household chooses the arrangement that results in the most advantageous tax situation - for example, an unmarried cohabitating couple with two children might each claim a child and file as a head of household if it lowers their combined taxes.

Next, we divide tax-filing unit records in each file into fifteen demographic subgroups, based on marital status, the number of dependents, and whether the primary taxpayer or their spouse is age sixty-five or older. Records from the two files are then matched within the same demographic cell, with certain exceptions. Because the CPS contains fewer head of household (single parent with children) tax-filing units than the SOI, we match some single childless CPS records, and some married CPS records with head-of-household filers on the SOI. The deficit in head-of-household filers on the CPS likely reflects some combination of misreporting of filing status on the SOI and

3. For a complete description of the SOI file, see Internal Revenue Service (2012).

4. For a general description and evaluation of statistical matching, see Cohen (1991) and D'Orazio, Di Zio, and Scanu, (2006). 
a failure of the algorithm that creates tax units for the CPS to account for complex living arrangements.

Within each demographic subgroup, we fit an ordinary least squares regression model on the SOI. The model predicts total income as a function of all the income items that are common to both the SOI and the CPS (wages, interest, dividends, rental income, business income and losses, pension income, and unemployment insurance). We apply the coefficients from that regression to the records in both files to construct a predicted income variable, and sort records in both files in descending order by the predicted value. The SOI record with the highest predicted income is matched to the CPS record with the highest predicted income. Of the two records, the one with the lower weight is matched to only one corresponding record. The record with the higher weight is "split," and is available (with its weight reduced) to be matched to the next record in the other file. (In practice, the highest income SOI records have very low weights, so the top CPS record can be matched to many SOI records). We repeat that process until all the SOI records are exhausted. Residual CPS records (those with the lowest predicted income) are assumed to represent households that did not file a tax return.

Each matched pairing results in a new record with the demographic characteristics of the CPS record and the income reported in the SOI. Some types of income, such as certain transfer payments and in-kind benefits, appear only in the CPS; values for those items were drawn directly from that survey. Income values for CPS records that represent nonfiling units are taken directly from the CPS.

Next, we rebuild households from tax-filing units based on the relationships as reported in the CPS. In general, CPS tax filing units will have been split or matched to multiple SOI records. In households where multiple split tax units are present, multiple instances of the household are created, covering all possible combination of tax units, with the weight appropriately allocated.

\subsubsection{Measuring Income}

This analysis uses three measures of household income: market income; market income plus government transfers (referred to as before-tax income); and market income plus government transfers, minus federal taxes paid (referred to as after-tax income).

Market income includes the following components:

- Labor income: Cash wages and salaries, including those allocated by employees to 401(k) plans; employer-paid health insurance premiums (as measured by the CPS); the employer's share of Social Security, Medicare, and federal unemployment insurance payroll taxes; and the share of corporate income taxes borne by workers. 
- Business income: Net income from businesses and farms operated solely by their owners, partnership income, and income from $\mathrm{S}$ corporations.

- Capital gains: Profits realized from the sale of assets. Increases in the value of assets that have not been realized through sales are not included in market income.

- Capital income (excluding capital gains): Taxable and tax-exempt interest, dividends paid by corporations (but not dividends from S corporations, which are considered part of business income), positive rental income, and the share of corporate income taxes borne by capital owners.

- Other income: Income received in retirement for past services and other sources of income.

Government transfers consist of cash payments from Social Security, unemployment insurance, Supplemental Security Income, Temporary Assistance for Needy Families ([TANF] and its predecessor, Aid to Families with Dependent Children [AFDC]), veterans' programs, workers' compensation, and state and local government assistance programs. It also includes the value of in-kind benefits such as Supplemental Nutrition Assistance Program vouchers (formerly known as food stamps), school lunches and breakfasts, housing assistance, energy assistance, and benefits provided by Medicare, Medicaid, and the Children's Health Insurance Program (measured by the Census Bureau's estimates of the average cost to the government of providing that insurance).

After-tax income is the sum of market income and government transfers, minus federal taxes paid. This analysis includes four federal taxes: individual and corporate income taxes, social insurance (payroll) taxes, and excise taxes. Those taxes have generally accounted for over 95 percent of federal revenues. Some smaller tax sources (estate and gift taxes, customs duties, Federal Reserve earnings, miscellaneous receipts) are omitted, either because of uncertainty surrounding their incidence or difficulties in estimating their distribution.

\subsubsection{Incidence of Federal Taxes}

Households are assumed to bear the economic cost of the taxes they pay directly, such as individual income taxes and the employee's share of payroll taxes. Employers are assumed to pass on their share of payroll taxes to employees by paying lower wages than they would otherwise pay, so the employer's share of payroll taxes is included in household before-tax income and in household taxes.

Excise taxes are generally assumed to fall on households according to their consumption of taxed goods (such as tobacco and alcohol). Excise taxes on intermediate goods, which are paid by businesses, were attributed to households in proportion to their overall consumption. We assume that 
each household spends the same amount on taxed goods as the average for households with comparable income and demographics as reported on the Bureau of Labor Statistics' Consumer Expenditure Survey.

Far less consensus exists about how to allocate corporate income taxes (and taxes on capital income generally). In this analysis, we allocated 75 percent of the burden of corporate income taxes to owners of capital in proportion to their income from interest, dividends, rents, and adjusted capital gains. Capital gains are adjusted by scaling them to their long-term historical level given the size of the economy and the tax rate that applies to themrather than actual capital gains so as to smooth out any large year-to-year variations in the total amount of gains realized. We allocated 25 percent of the burden of corporate income taxes to workers in proportion to their labor income.

\subsubsection{Adjusting for Household Size}

Households are the unit of analysis. A household includes all people living in a single housing unit. The presumption is that households make joint economic decisions, which may not be true in every case (in a group house, for example). Households may comprise more than one taxpaying unit, such as a married couple and their adult children living together. In those cases, the income and taxes of each taxpaying unit are added together.

Larger households need more income to achieve the same standard of living as smaller ones. At the same time, there are some economies of scale in consumption, especially in housing consumption. To account for varying needs of different size households, and following a standard practice in the income inequality literature, income is adjusted for household size by dividing income by an adjustment factor equal to the square root of the number of people in the household, counting adults and children equally.

Some results are presented for various subgroups of the population, such as the lowest 20 percent or the top 1 percent. In constructing those subgroups, households are ranked by income that is adjusted for household size. Each subgroup of the population contains an equal number of people, but because households vary in size, subgroups generally contain unequal numbers of households.

\subsection{Limitations of the Analysis}

We strive to measure income, transfers, and taxes as broadly as possible. However, there are several conceptual and measurement issues that limit the analysis.

\subsubsection{Annual Income}

This study presents a series of annual snapshots of household income. Because annual income is only one perspective for evaluating economic well- 
being, focusing exclusively on that measure may provide an incomplete picture. For example, a household's income in any given year may not accurately represent its economic well-being over a longer period. Measuring income over a longer time frame, even over a lifetime, might provide a better indicator of a household's economic circumstances. Likewise, a household's consumption - rather than its income - may present a more accurate picture of its welfare or economic well-being (Slesnick 2001).

Household income measured over a multiyear period is more equally distributed than income measured over one year, although only modestly so (Congressional Budget Office 2005; Kopczuk, Saez, and Song 2010). That is somewhat surprising given the fairly substantial year-to-year movement of households across income groups, but much of the movement involves relatively small changes in income that, although sufficient to push households into a different income group, are not large enough to greatly affect the overall distribution of income. Multiyear income measures also show the same pattern of increasing inequality over time as is observed in annual measures.

Household consumption is more equally distributed than household income. The question of trends in consumption inequality is less settled, however. Several influential studies have documented that consumption inequality has not increased as much as income inequality (Slesnick 2001; Krueger and Perri 2006). Later studies have employed new techniques to account for errors in the measurement of consumption, and found much greater increases in consumption inequality (Aguiar and Bils 2011; Attanasio, Hurst, and Pistaferri 2012). An important measurement issue is the degree to which data on the consumption of US households adequately capture consumption by high-income households, a group whose rising income accounts for much of the observed increase in annual income inequality.

\subsubsection{Capital Gains and Pensions}

Two aspects of our income definition bear further discussion-capital gains and pensions. We measure capital gains income when realized, rather than as it accrues. For pensions, we measure the income when received or withdrawn (in the case of defined-contribution type retirement accounts). That decision is partly based on data availability, and partly from a desire to use the same accounting framework when measuring income and taxes.

Benchmark definitions of income differ in their treatment of these income sources (see Johnson and Fixler, chapter 8, this volume, for more detailed discussion). Under a comprehensive Haig-Simons income definition, often operationalized by defining income as equal to consumption plus the change in net worth, both capital gains and pensions would be counted when accrued. Under the Bureau of Economic Analysis definition of personal income, both realized and unrealized capital gains are excluded. Pension payments are excluded, but employer contributions to pension funds are 
included when made, and the interest and dividends (but not capital gains) earned by pension funds are included as they accrue. The measure of household income recommended by the Canberra Group excludes capital gains, and counts pension income when received (Canberra 2011).

In practice, efforts to measure pensions and gains on an accrual basis are hampered by data constraints. Existing household surveys and administrative data simply do not capture well the increase in personal assets at the household level. The value of benefits promised under defined-benefit plans are particularly difficult to measure as they accrue. While there has been some progress on measuring capital income at the household level as it accrues, based on asset holdings and the assumption that all households receive the same rate of return on a given asset type, those estimates are limited to certain years (Armour, Burkhauser, and Larrimore 2013; Smeeding and Thompson 2010).

Our view is that, in the absence of lifetime income data, it is impossible to accurately apportion the capital gains realized in a single year over multiple years, and that the practical choice is between counting the gain as income when realized or allotting only part or none of it to current income. ${ }^{5}$ Omission seems the worse choice, especially because the favorable tax treatment of capital gains income has created strong incentives for high-income taxpayers to recharacterize ordinary income as capital gains. Excluding capital gains would reduce the market income Gini by 0.014 in 1979 and by 0.011 in 2010. Excluding the gains shifting in 1986 and 1987, the maximum effect of capital gains occurred in 2007 (0.027 Gini points) and 2005 (0.025 Gini point).

The desire to examine the joint distribution of income and taxes also argues for including pension and capital gains income upon realization. The US income tax is assessed on such income when realized; there is some logic to using the same accounting principles for the measurement of income and taxes. Otherwise the misalignment in timing would show, for instance, very high tax rates on pensioners or on taxpayers whose primary income is capital gains. While in theory one could compute the taxes on such income on an accrual basis as well, doing so would making assumptions about future tax law, household economic circumstances, and the timing of pension receipt and the sale of assets.

\subsubsection{State and Local Taxes}

This analysis excluded state and local taxes because of the difficulty of estimating them for individual households over a long period. State sales taxes would be particularly challenging, as no major survey collects data on

5. Extensive examination of tax data on the sales of capital assets indicates that apportioning gains across years on the basis of a single year's realizations would lead to significant error. See Congressional Budget Office, Perspectives on the Ownership of Capital Assets and the Realization of Capital Gains (May 1997). 
sales taxes paid by households. It is unclear how the omission of those taxes affects conclusions about trends in the progressivity of the entire tax system.

In the time frame studied here, state and local taxes have ranged between 8.2 percent and 9.3 percent of gross domestic product-equal to about 40 percent to 50 percent of total federal taxes. State and local taxes have three primary components, and the composition of receipts has been fairly stable over time. Sales taxes are the largest source, accounting for 34 percent of state and local revenue in 2010. Those taxes are generally assumed to be roughly proportional to consumption, making the tax regressive with respect to income (because lower-income households consume a greater proportion of their income than do higher-income households). Property taxes accounted for 33 percent of state and local revenues in 2010. The progressivity of those taxes depends critically on the assumptions about the incidence of the taxes, which is a matter of considerable debate. State individual income taxes, which accounted for 21 percent of state and local revenues in 2010, are much less progressive than the federal individual income tax because the rate structures for state-level income taxes are flatter than those at the federal level and any refundable credits are small. Thus, though different analysts have reached different conclusions about whether state and local taxes on net are proportional, progressive, or regressive, they are clearly less progressive than the federal tax system (Phares 1980; Pechman 1985; Chamberlain and Prante 2007; and ITEP 2009). Consequently, analysis of the entire tax system would show less progressivity than analysis of the federal tax system alone. It is more difficult to know how state and local taxes have affected trends in tax progressivity, however.

\subsubsection{Misreporting of Transfer Income}

For most transfer payments, estimates of participation and benefit amounts are taken from the CPS. For Social Security and unemployment insurance benefits, which are partially taxable, estimates come from a combination of tax and information returns and survey reporting. Unfortunately, reporting rates for transfer payments, especially means-tested transfers, on the CPS are relatively low, and have generally been declining over time. For example, the percentage of annual food stamp benefit dollars captured in the CPS declined from 67 percent in 1993 to 55 percent in 2005 (Wheaton 2007). For TANF/AFDC, reporting rates declined from 75 percent in 1993 to 57 percent in 2005 .

We have corrected for some misreporting of transfers in some years, using data from the Transfer Income Model (TRIM3). ${ }^{6}$ That model applies the

6. The model was developed and is maintained by the Urban Institute, with funding primarily from the Department of Health and Human Services, Office of the Assistant Secretary for Planning and Evaluation. TRIM3 requires users to input assumptions and interpretations about economic behavior and the rules governing federal programs. Therefore, the conclusions presented here are attributable only to the authors. 
rules of several transfer programs to each household in the CPS to determine if households are eligible for benefits and, if so, the size of the benefit they can receive. Households that report receiving benefits, and who appear eligible, are given the computed amount of the benefit. Households that are ineligible are assumed to receive no benefits, even if they report receiving them. New participants are created from eligible households who did not report receiving benefits in such a way as to match the size and characteristics of recipients on the basis of agencies' program data. The model targets the number of recipients rather than the overall amount of benefits, but the estimated benefit amounts approximate the agencies' totals.

To assess the sensitivity of its main analysis to the misreporting of transfers, we combined estimates of transfer payments using TRIM3 with our merged data file. For the programs covered by TRIM3 - food stamps, SSI, TANF/AFDC, and housing subsidies-we replaced benefits as reported in the CPS with benefits as estimated using TRIM3, and recomputed our inequality measures. We made those estimates for 1993 and 2004, the earliest and latest years for which TRIM3 estimates are available at the time of the analysis.

Adjusting for the misreporting of transfer payments adds income to the bottom of the distribution. Consequently, the Gini index adjusted for misreporting is lower than the unadjusted Gini index. For 1993, reporting adjustments cause the Gini index to fall from 0.005 , or by about 1 percent. For 2004, reporting adjustments lower the Gini index by 0.004 , or by 0.8 percent. The adjustment had a smaller impact in the latter year, despite the fact that underreporting of transfer income grew, because transfer income was a smaller share of household income in that year. Specifically, the misreporting adjustments were larger in 2004 as a share of transfer income but smaller as a share of total household income. Even for households at the bottom of the distribution, transfer income grew more slowly than other income over the 1993 to 2004 period, mitigating the effect of increased misreporting on the observed degree of inequality.

While that result suggests that misreporting of transfers have not had a large impact on our measures of income inequality, that result is not definitive because of the limited number of transfer programs covered and the limited timeframe. Importantly, no adjustments have been made for nonmeans-tested transfers (such as Medicare) or for Medicaid. While Medicare has fairly high reporting rates, misreporting of Medicaid is a significant issue. A planned extension of our work is to make a full set of misreporting adjustments, to cover all major transfer programs and years.

\subsection{The Distribution of Household Income}

This section begins with an examination of trends in the distribution of income after transfers and federal taxes. It then examines changes in the 
market income distribution in more detail, and finally isolates the effect of taxes and transfers on the income distribution.

\subsubsection{The Distribution of Income after Federal Taxes and Transfers}

Income after taxes and transfers is the income measure that most closely corresponds to the ultimate resources available to households. From 1979 to 2010, mean after-tax household income grew much more rapidly for the highest-income households than for the rest of the income distribution (see figure 7.1). ${ }^{7}$ Over the full thirty-two-year period, annual real income growth for the top percentile averaged 3.4 percent. For other households in the highest-income quintile (the 81st through 99th percentiles), average after-tax income grew at an average annual rate of 1.6 percent. That rate somewhat exceeded that of the lowest quintile (1.1 percent) and the middle three quintiles (1.2 percent).

Income for the top percentile has been quite volatile: after a period of strong growth in the early 1980s, it spiked in 1986 and fell in 1987, reflecting an acceleration of capital gains realizations into 1986 in anticipation of the scheduled increase in tax rates the following year. Income growth for the top 1 percent of the population rebounded in 1988 but fell again with the onset of the 1990 to 1991 recession. By 1994, after-tax household income was 51 percent higher than it had been in 1979. Income growth accelerated in 1995, averaging more than 20 percent per year through 2000. After falling sharply during the recession and stock market drop in 2001, average real after-tax income for the top 1 percent of the population almost doubled between 2002 and 2007. Large declines in capital income associated with the recession in 2008 and 2009 caused a steep decline in top incomes between 2007 and 2009. Top incomes partially rebounded in 2010.

As a result of that uneven income growth, shares of total after-tax income shifted in favor of higher-income households. Measured across business cycle peaks, the share of income received by the top 1 percent more than doubled, from about 8 percent in 1979 to over 16 percent in 2007, before declining to 13 percent in 2010. The share received by other households in the highest income quintile remained relatively flat over the1979 to 2010 period, while the share of income accruing to each of the four lowest-income quintiles fell by over a percentage point.

The upward shift in after-tax income shares is reflected in the Gini coefficient for after-tax income (see figure 7.2). That index rose by 0.106 points from 1979 to 2007, before falling 0.030 points from 2007 to 2010. The index increased in almost every year during that span, declining only with the recessions in 1990 to 1991, 2001, and 2007 to 2009. It also declined in 1987 largely due to income shifting associated with the Tax Reform Act of 1986. The rate of increase was not constant, however. The Gini index increased

7. Inflation is measured using the personal consumption expenditures price index. 


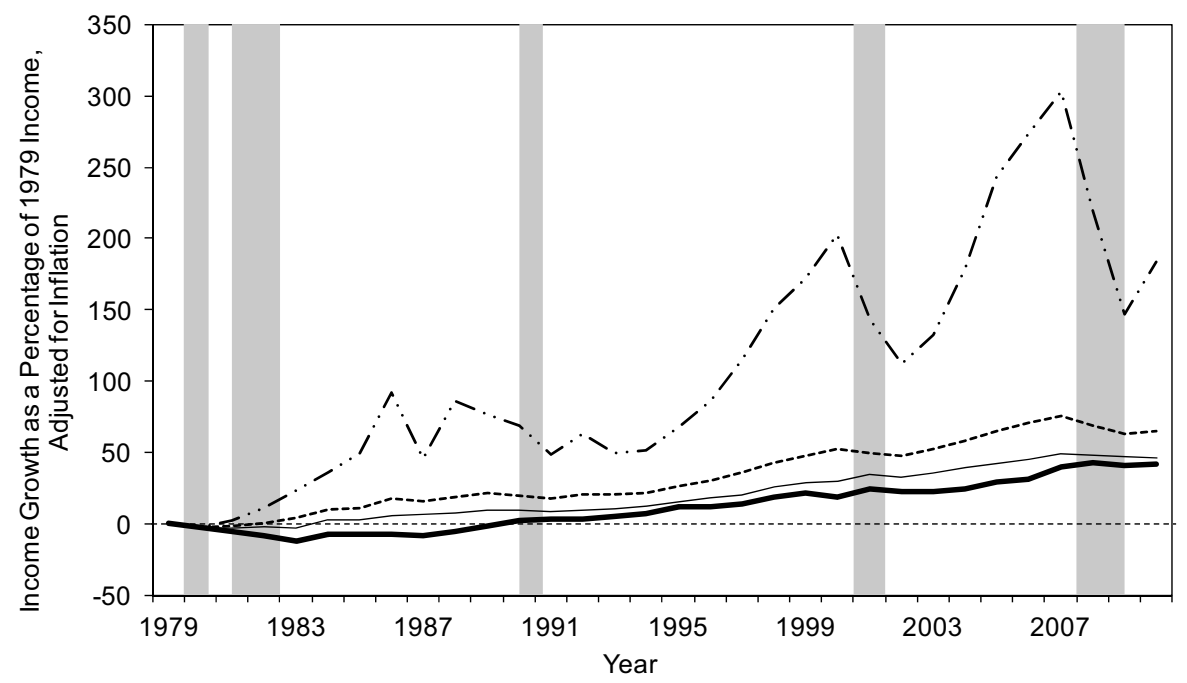

-.-Top 1 Percent -----81st-99th Percentiles — 21st-80th Percentiles — Lowest Quintile

Fig. 7.1 Cumulative growth in average after-tax income by income group, 1979-2010

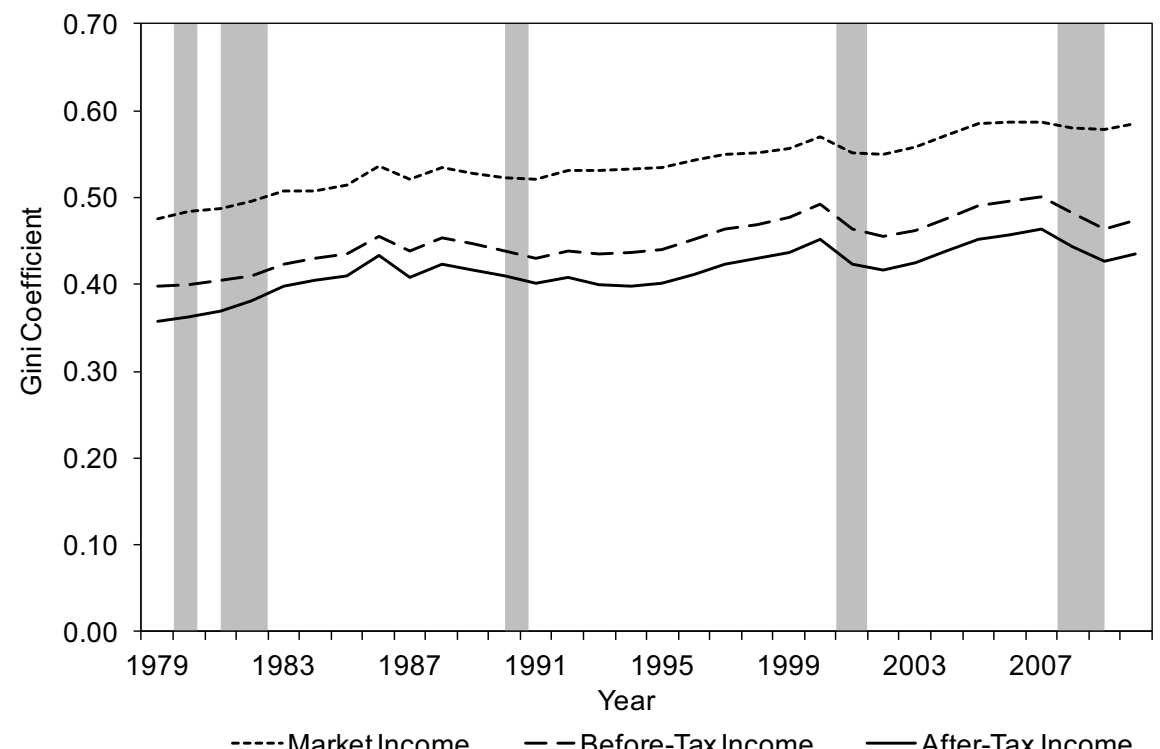

Fig. 7.2 Gini coefficients, 1979-2010 
at a rate of about 0.003 points per year in the 1980 s expansion, 0.006 points per year in the 1990s expansion, and 0.010 points per year during the expansion in the 2000s.

\subsubsection{The Distribution of Market Income}

An increase in the inequality of market income was the primary cause of the widening inequality of after-tax income. With a few exceptions, the Gini coefficient for after-tax income parallels that of market income. From 1979 to 2007, the increase in the Gini for market income was almost identical to the increase in the Gini for after-tax income (though those measures deviated somewhat in the recession of 2008 to 2009 , discussed later).

A useful property of the Gini index is that it is possible to determine the contribution of different income sources to the increase in overall income inequality through a simple decomposition. The contribution of each income source to the Gini index for total market income is the product of the concentration index (often called a pseudo-Gini) for that income source and the share of total market income attributable to that source. ${ }^{8}$ Thus, changes in the concentration of income from a source such as labor income will have a much greater effect on overall income concentration than an equivalent change in the concentration of another income source (such as capital income) because labor income is a much larger share of total income. Changes in the Gini for market income can be decomposed into changes in the weight placed on each source, and changes in the concentration index for each source.

A concentration index differs from a Gini index for each source because in calculating the concentration index, the population is ranked by total market income rather than by income from that source, as they would be in calculating the Gini index for that source. The concentration index captures two effects: the concentration of income from that source, and the correlation of that income source with income from other sources (and hence with total income). The latter effect arises because households are sorted by total income when computing the metric. Thus, for example, the concentration index for labor compensation has increased over time both because compensation has become more unevenly distributed in favor of higher-compensation households and because compensation has become more highly correlated with other unevenly distributed sources of income, such as capital income. ${ }^{9}$

8. This derivation is reported in Shorrocks (1982) and Fei, Ranis, and Kuo (1978).

9. Lerman and Yitzhaki (1985) propose an alternative three-factor decomposition that decomposes the pseudo-Gini for each income source into the Gini coefficient for that source and a factor they term the Gini correlation, which measures the relationship between an income source and total income. 


\section{Decomposing Changes in Market Income Inequality by Income Source}

Looking first at the concentration of different income sources, it is clear that labor income is more evenly distributed across the income spectrum than capital income, and both are more evenly distributed than capital gains or business income (see figure 7.3). Concentration indexes for the major sources of income all increased - albeit irregularly — from 1979 to 2010, indicating rising inequality in the distribution of each source of income. Labor income became steadily more concentrated from 1979 through 1988, and then again in 1992 following the 1990 to 1991 recession. After remaining mostly unchanged during the rest of the 1990s, the concentration of labor income increased again from 1999 through 2002. From 2002 to 2005 the concentration was has declined slightly, before rising with the 2008 to 2009 recession.

Capital income (excluding capital gains) became increasingly concentrated beginning in the mid-1980s. Its concentration shows a clear cyclical pattern, rising in expansions and falling in recessions, probably reflecting differences in asset holdings across the income spectrum. Capital gains also became increasingly concentrated beginning in the early 1990s; unlike other income from capital, however, the degree of concentration of capital gains continued to rise through 2003 but fell thereafter. The concentration of business income was quite variable in the early part of the 1980s. Some of that variability might reflect changes in tax law in that period. After 1986, the concentration of business income rose steadily through 1991, declined

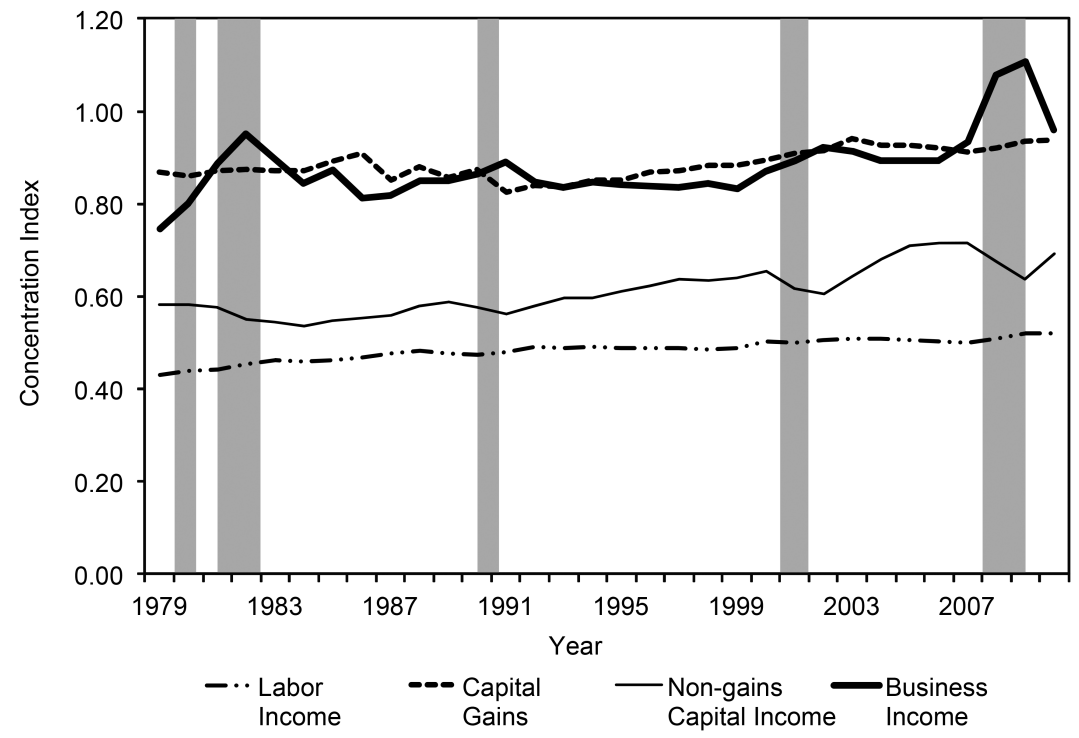

Fig. 7.3 Income concentration, by major source 
through much of the 1990s, before rising in the 2000 to 2002 period. Especially noteworthy is the large jump in the concentration of business income in 2008 and 2009, which was largely due to large business losses in that period.

Turning to the composition of market income, labor income is the largest income component, accounting for more than 70 percent of market income in most years between 1979 and 2007. The labor share of total income was at its high point, 75 percent, at the beginning of the period. That share generally rose in recessions (as other income sources are more cyclical) and fell in expansions, and by 2007 had reached a nadir of 66 percent. The 2008 to 2009 recession caused sharp drops in capital gains and other capital income, and consequently pushed the labor share back near its high points in 2009 and 2010. Capital income (excluding capital gains) is the next largest source, but even at its peak in 1981 it was only about 14 percent of market income. Since then, the share of total income from capital has declined to about 10 percent of total income in 2007, and to 8 percent in 2010. Income from capital gains rose from about 4 percent of market income in 1979 to about 9 percent in 2007, before falling to 4 percent in 2010. Business income and income from other sources (primarily private pensions) each accounted for about 8 to 9 percent of total income at the end of the period, up from about 4 percent apiece in 1979 .

The relative importance of changes in the concentration of particular income sources and shifts in the shares of market income represented by those sources in explaining trends in market income inequality varied over time (see table 7.1). Subperiods are defined here by whether the Gini coefficient rose or fell, and they loosely correspond with business cycles. From 1979 to 1988 , almost all of the increase of 0.059 points in the Gini index for total market income resulted from an increasing concentration of separate income sources, primarily labor income. Small shifts in the share of market income from less to more highly concentrated sources - in particular, from labor income to business and other income-explain only a small portion of the increase in the concentration of total market income over that period.

In contrast, from 1991 to 2000 - a period that saw an increase of 0.049 points in the Gini index - a shift to more concentrated sources explains about 45 percent of the overall increase in market income inequality, and an increase in the concentration within each source accounts for the other 55 percent. In that case, a decrease in the percentage of total income from labor and capital and an increase in the share from capital gains was a major factor, as was an increase in the concentration of both labor and capital income.

The reasons for the increase of 3.8 percentage points in the Gini index for total market income between 2002 and 2007 differ yet again. More than three-quarters of the total increase in the Gini index stemmed from an increase in the share of total income coming from more highly concentrated 


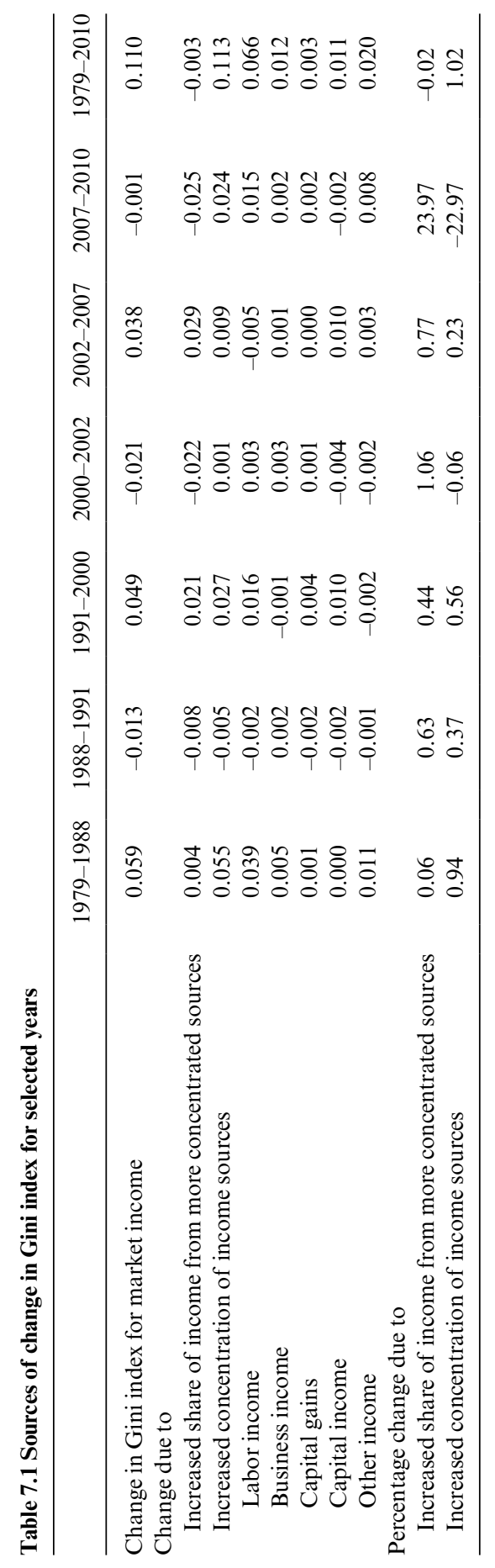


capital gains. An increase in the concentration of capital income accounts for most of the remaining increase. Labor income became somewhat less concentrated over that period, but the effect on overall income dispersion was small.

The 2007 to 2010 period saw little net change in the Gini for market income. That reflects two offsetting effects. First, capital and business income declined sharply, pushing up the labor share of market income. By itself, that effect would have caused the Gini coefficient to rise by 0.025 points. At the same time, however, labor income and other income grew more concentrated, largely offsetting the effect of the changing mix of incomes.

Over the 1979 to 2007 period as a whole, the increased concentration of the individual sources of market income accounted for more than 100 percent of the total increase in the Gini index, as all major sources of market income became more highly concentrated in favor of higher-income households. Labor income was the biggest contributor because it is by far the largest source of income, even though the increase in the concentration of labor income was smaller than the increase in concentration for other sources. ${ }^{10}$

\subsubsection{Income Changes for the Top 1 Percent of the Population}

The rapid growth of average market income for the 1 percent of the population in households with the highest income was a major contributing factor to the increase in household income inequality between 1979 and 2010. Without the income growth at the very top of the distribution, income dispersion still would have increased, but not by as much. Recalculating the Gini index by excluding the 1 percent of the population in households with the highest income in each year reduces the level of the measured market income inequality (from .586 to 0.515 in 2010) and also the measured increase in market income inequality over the full 1979 to 2010 period (from 0.110 to 0.082 ).

Average market income for the highest income grew very rapidly over that period. At its peak in 2007, mean income for that group had almost quadrupled. The pattern of market income growth is similar to the pattern of after-tax income growth: tremendous growth in the late 1990s, sharp declines during the recession and stock market decline in 2001, followed by another period of rapid growth between 2002 and 2007. Large declines in capital income associated with the recession in 2008 and 2009 caused a steep decline in top incomes between 2007 and 2009. Top incomes partially rebounded in 2010.

Between 1979 and 2010, the composition of household income for the 1 percent of the population in households with the highest income changed

10. Many studies have documented the increasing inequality of labor income. Despite a voluminous literature on the subject, the causes of this are still a somewhat unsettled matter. See for example, Lemieux (2010) and the references therein. 


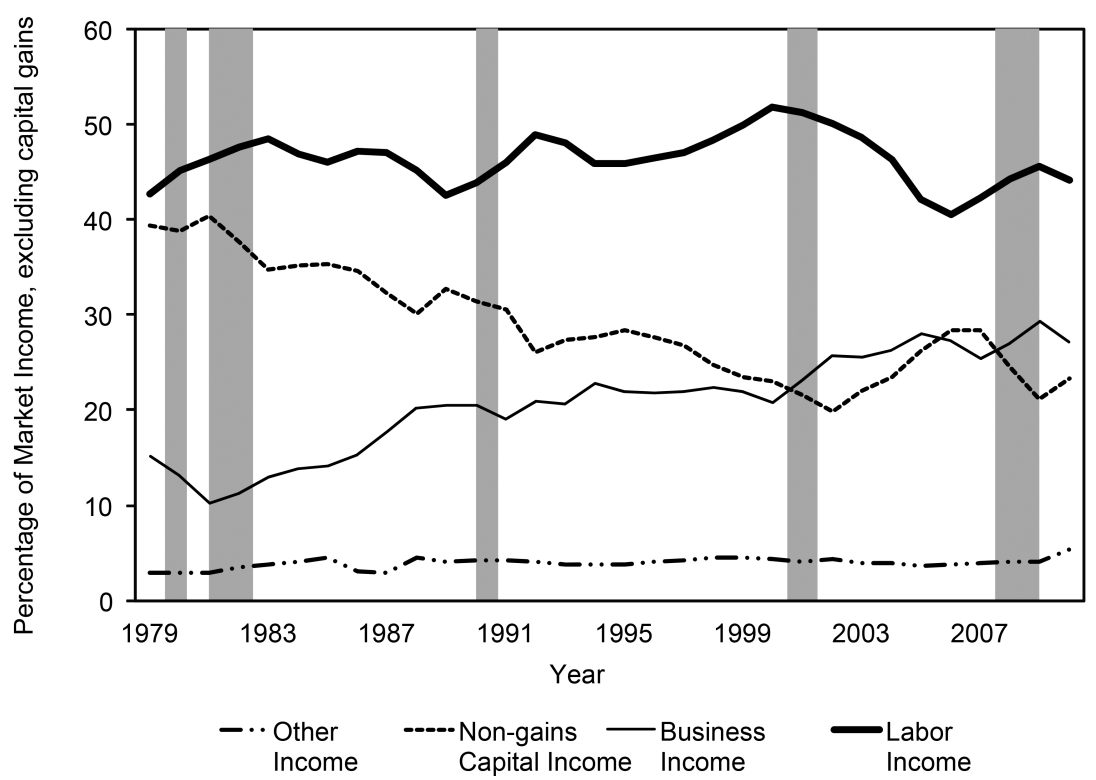

Fig. 7.4 Shares of market income, by source, for the top 1 percent of households, 1979-2010

significantly. Because of the volatile nature of income from capital gains realizations and its significance for the highest-income households, it is more illuminating to look at sources of income as shares of market income excluding capital gains. From 1979 through 2010, wages and other labor compensation varied from 40 percent to 50 percent of total income excluding capital gains, with no apparent trend (see figure 7.4). Interestingly, the labor share rose while top incomes grew rapidly during the late 1990s, but declined as top incomes grew rapidly during the middle of the first decade of the twenty-first century.

Capital income excluding capital gains - in other words, interest, dividends, and rents - has generally been a declining source of income among the highest-income households. Its share dropped from 40 percent of market income excluding capital gains in 1979 to 20 percent in 2002 and then increased to about 28 percent by 2007. It then declined in the 2008 to 2009 recession, before rebounding somewhat in 2010. Over the same period, the share of income from business activities has grown sharply and fairly steadily, increasing from a low of 10 percent of total market income excluding capital gains in 1981 to nearly 30 percent in 2010.

Capital gains are the most volatile source of income, and their importance as a share of household income for the top 1 percent of the population has fluctuated. That fluctuation appears to reflect movements in stock prices and changes in tax law. Between 1979 and 1985, capital gains were equal to 20 percent to 30 percent of market income excluding capital gains for the 
top 1 percent; in 1986, they spiked to more than twice that share. The ratio of income from capital gains to other market income declined throughout the late 1980s and then began to pick up in the mid-1990s before entering a period of rapid growth starting in 1995. That ratio peaked at 34 percent of market income in 2000 before falling to 15 percent in 2002 and then rebounding to 36 percent in 2007 and falling to 11 percent in 2011.

The fall in capital income and the increase in business income may in part reflect a recharacterization of income. Following the Tax Reform Act of 1986, which lowered the top statutory tax rate on individual income below the top rate on corporate income, many $\mathrm{C}$ corporations (which are taxed separately from their owners under the corporate income tax) were converted to $\mathrm{S}$ corporations (which pass corporate income through to their shareholders, where it is taxed under the individual income tax). As a result, corporate dividend income and capital gains from the sale of corporate stock were converted into $\mathrm{S}$ corporation income, which is counted here as part of business income. Business income jumped in the 1986 to 1988 period as those conversions began and it continued to grow rapidly throughout the 1990s and early twenty-first century as more conversions occurred and new businesses were formed as $\mathrm{S}$ corporations rather than $\mathrm{C}$ corporations.

The changing composition of income for the highest-income households reflects a much longer trend. Over the entire twentieth century, capital income declined sharply in importance for high-income taxpayers. The wage share of income for the top income groups was higher in 2007 than before World War II, as highly compensated workers have replaced people whose income is from property or securities at the top of the income distribution (Piketty and Saez 2003).

Numerous explanations for the rise of the highest incomes have been proffered, though it is a unsettled issue. ${ }^{11}$ One theory is that that the compensation of "superstars" (such as actors, athletes, and musicians) may be especially sensitive to technological changes. Another line of research has focused on the very large pay increases for top corporate executives, with some arguing that weaknesses in corporate governance have enabled corporate executives to overpay themselves and others arguing that increases in corporate size and complexity have made firms more willing to pay large salaries to attract and keep the best executives. Still others have focused on the form of compensation, arguing that the increasing importance of stock options in executive compensation has caused that compensation to grow rapidly during periods of rapid appreciation in the stock market.

\subsection{The Effect of the Tax and Transfer System on Income Inequality}

Changes in the distribution of after-tax household income were primarily driven by changes in the market income distribution. However, changes in 
the distribution of government transfer payments and federal taxes played some role.

Overall, transfers and federal taxes reduce income inequality. Transfers that are a decreasing percentage of market income as income rises (progressive transfers) lower the Gini index by boosting income for people at the bottom of the scale. Taxes that are an increasing percentage of before-tax household income as income rises (progressive taxes) make income more equal by reducing income by more for higher-income households. In addition, the earned income tax credit, which in this analysis is included with federal taxes (though some of its benefits are conveyed in the form of government payments), has an effect on the income distribution similar to that of transfers by raising the after-tax income of lower-income households.

The equalizing effect of transfers and taxes depends on their degree of progressivity and on their size relative to household income. Holding the size of transfers and taxes constant, an increase in the progressivity of transfers and taxes will reduce income inequality. Holding the degree of progressivity constant, an increase in the size of a progressive transfers and tax system will also reduce inequality.

The effect of transfers and taxes on the dispersion of household income can be seen by comparing the Gini index for market income with the Gini index for after-transfer, before-tax income and the Gini index for aftertransfer, after-tax income. A proportional transfer and tax system would leave the Gini index for after-transfer, after-tax income equal to that for household market income. Because both transfers and taxes are progressive in the United States, they reduce the Gini index. The dispersion of after-tax income in 2010 is about three-fourths as large as the dispersion of market income. Transfers have been more redistributive than taxes, and their effect has fluctuated more.

The redistributive effect of the tax and transfer system has varied over the period (see figure 7.5). In 1979, transfers and taxes reduced the Gini index by 0.118 . The effect of taxes and transfers rose and fell over ensuing years, varying with economic conditions and changes in tax and transfer policy. In 2007, immediately before the recession, transfers and taxes reduced the Gini index by 0.122 , almost identical to the effect in 1979 . The effect of taxes and transfers rose rapidly in the 2008 to 2010 period, so by 2010, taxes and transfers reduced the Gini index by 0.152 points, the largest reduction seen in the period. Much of that increase reflects temporary policy responses to the recession, which are not expected to persist.

\subsubsection{Government Transfer Payments}

In 2010 , transfers reduced the income inequality by 0.11 . Prior to the 2008 to 2009 recession, the redistributive effect of transfers fluctuated within a fairly narrow band, reducing the Gini coefficient by between 0.08 and 0.10 points. The effect of transfers was flat for most of the 1980s, rose in the early 


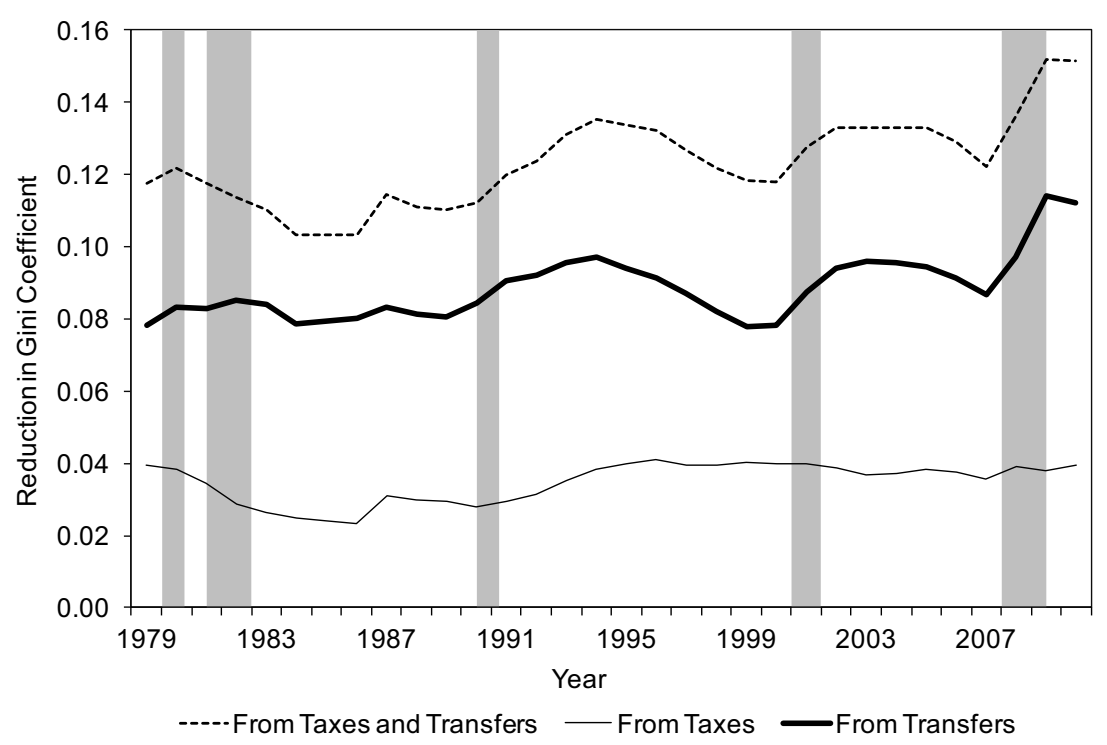

Fig. 7.5 Reduction in income inequality from taxes and transfers, 1979-2010

1990s, then declined in the latter part of that decade. The effect of transfers rose again around the 2001 recession and the 2008 to 2009 recession. Most of those movements reflected changes in the overall size of the transfer system.

The amount of government transfer payments - including federal, state, and local transfers - fluctuated with the business cycle (see figure 7.6). Measured peak to peak - 1979 to 2007-transfers rose from around 10.9 percent of market income to 13.5 percent. Transfers then rose sharply as a share of market income in 2008 to 2010, reflecting several factors. First, transfers rose because some programs, such as unemployment insurance and the Supplemental Nutrition Assistance Program (SNAP), function as automatic stabilizers, naturally rising in recession as market incomes decline. Additionally, several policy changes temporarily increased the generosity of transfer programs - unemployment benefits were increased and the maximum number of months recipients could receive benefits was expanded; and the maximum benefit for SNAP was increased. Finally, even without an increase in transfer payments the steep decline in market income caused the ratio of transfers to market income to rise. All of these effects should fade as the economy recovers.

Social Security is the largest transfer program, equaling about 6.6 percent of household market income on average over the period studied. Benefits have been a fairly stable percentage of market income, with the most notable increase occurring in 2008 and 2009. Even though average Social Security benefits have grown more slowly than average income, the population receiv- 


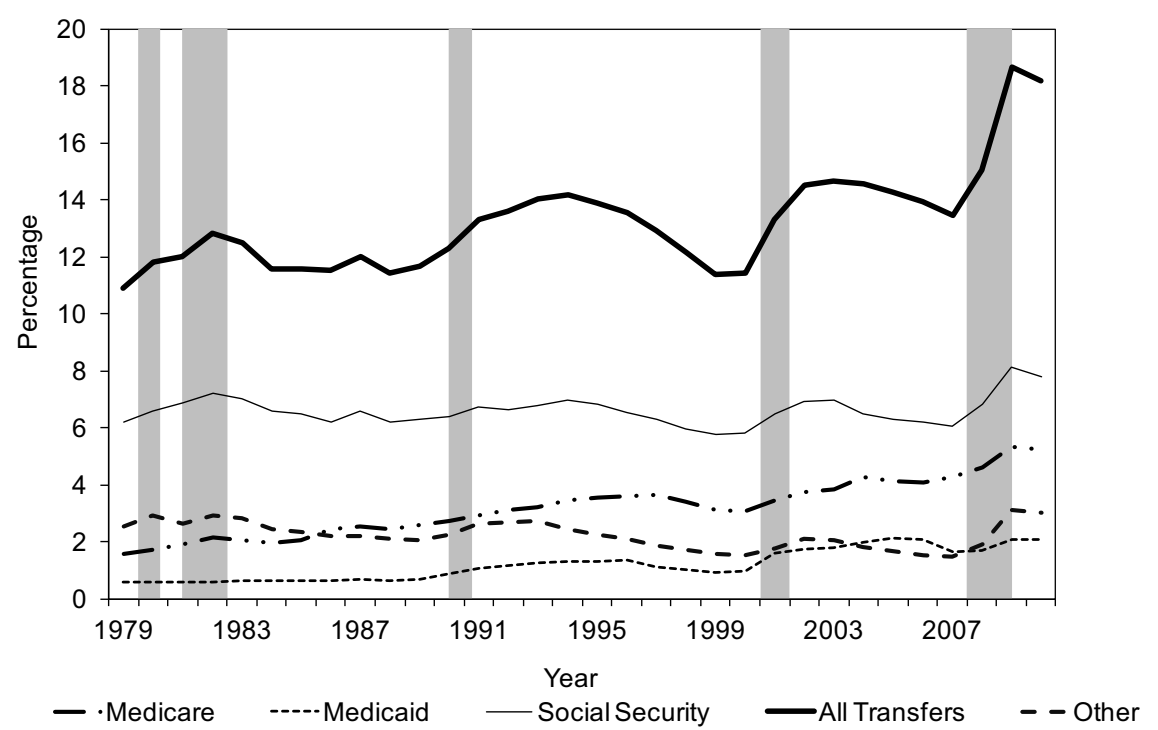

Fig. 7.6 Transfers as a percentage of household market income, 1979-2010

ing benefits has grown faster than the overall population, holding benefits fairly flat as a share of market income. Medicare and Medicaid benefits have both grown rapidly as a share of market income, by about 3.5 and 1.5 percentage points respectively. This reflects rapid growth in health-care costs and, in the case of Medicaid, expanded eligibility. Other transfers (including SNAP and unemployment benefits) declined from nearly 3 percent of household market income at their peak in 1982 to under 2 percent by 2007 before rebounding during the recent recession.

The shifts in the relative importance of different transfer programs since 1979 moved the distribution of transfer benefits away from households in the lower part of the income spectrum to some extent (see figure 7.7). Rapid growth in Medicare, which is not means-tested, tended to shift more transfer income to middle- and upper-income people. At the same time, spending on Aid to Families with Dependent Children and its successor, Temporary Assistance for Needy Families, has declined relative to market income; benefits from those means-tested programs are heavily concentrated at the bottom of the income scale. As a result, households in the lowest-income quintile received 56 percent of federal transfer payments in 1979 and 42 percent in 2010. The upward shift in the distribution of transfers tended to reduce the redistributive effect of the transfer system.

In sum, the transfer system grew somewhat larger over the three-plus decades studied, measured peak to peak, while becoming less skewed to the bottom of the income distribution. This larger, less targeted transfer system 


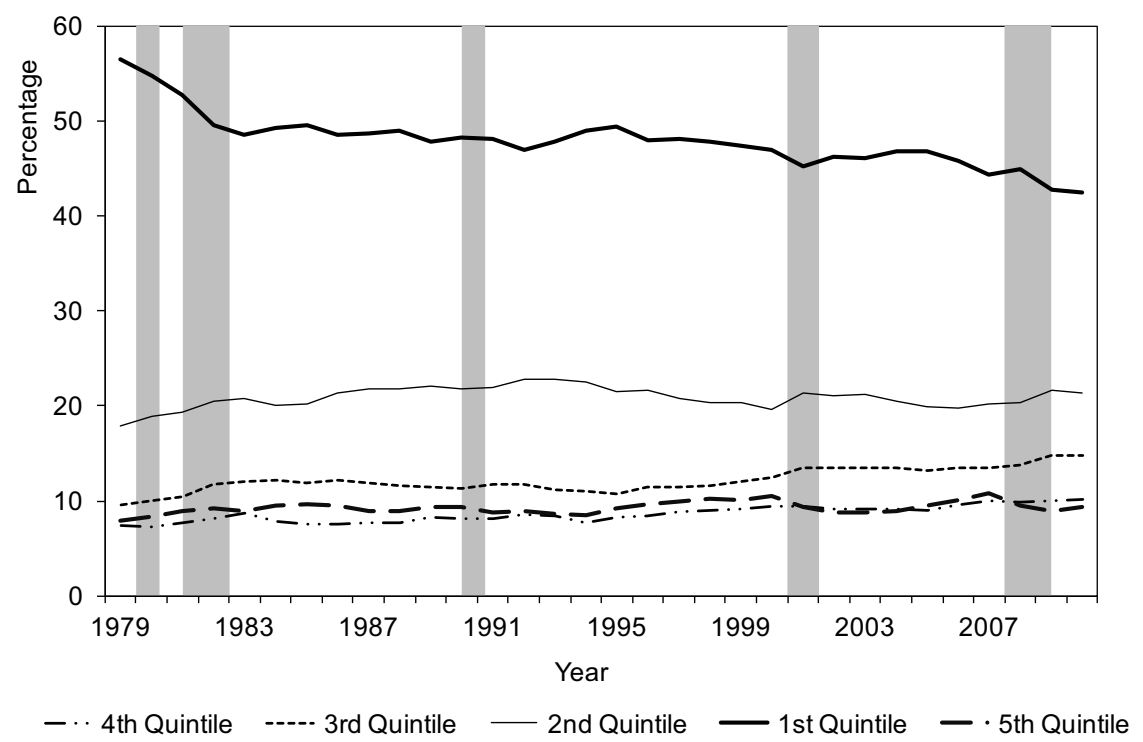

Fig. 7.7 Share of total transfers, by market income group, 1979-2010

had a roughly similar effect on income inequality in 2007 as the system in place at the beginning of the period. The effect of transfers on inequality rose quite a bit in the recent recession as the size of the transfer system, relative to market income, grew strongly; however, much of that effect is expected to fade as the economy recovers.

\subsubsection{Federal Taxes}

The effect of taxes on the distribution of after-tax income has been remarkably stable. In many ways, trends in the tax system are the mirror image of those seen in the transfer system. Over the three decades studied, the tax system grew smaller, but tax payments grew more skewed to the top of the distribution. Those effects approximately netted out, leaving a tax system that reduces inequality by about the same amount- -0.04 Gini points - at the beginning and the end of the period.

\section{Average Federal Tax Rates}

The overall average federal tax rate has declined from 22 percent of household income in 1979 to 18 percent in 2010 (see figure 7.8). The average tax rate declined in the early 1980s then rose through much of the 1980s and 1990s. It peaked at 23 percent in 2000, and then dropped sharply following the 2001 recession and tax legislation enacted in 2001 and 2003, falling to just under 20 percent in 2003, lower than any year since 1979. The rate fell again substantially in the 2008 to 2010 period, as a new round of tax reduc- 


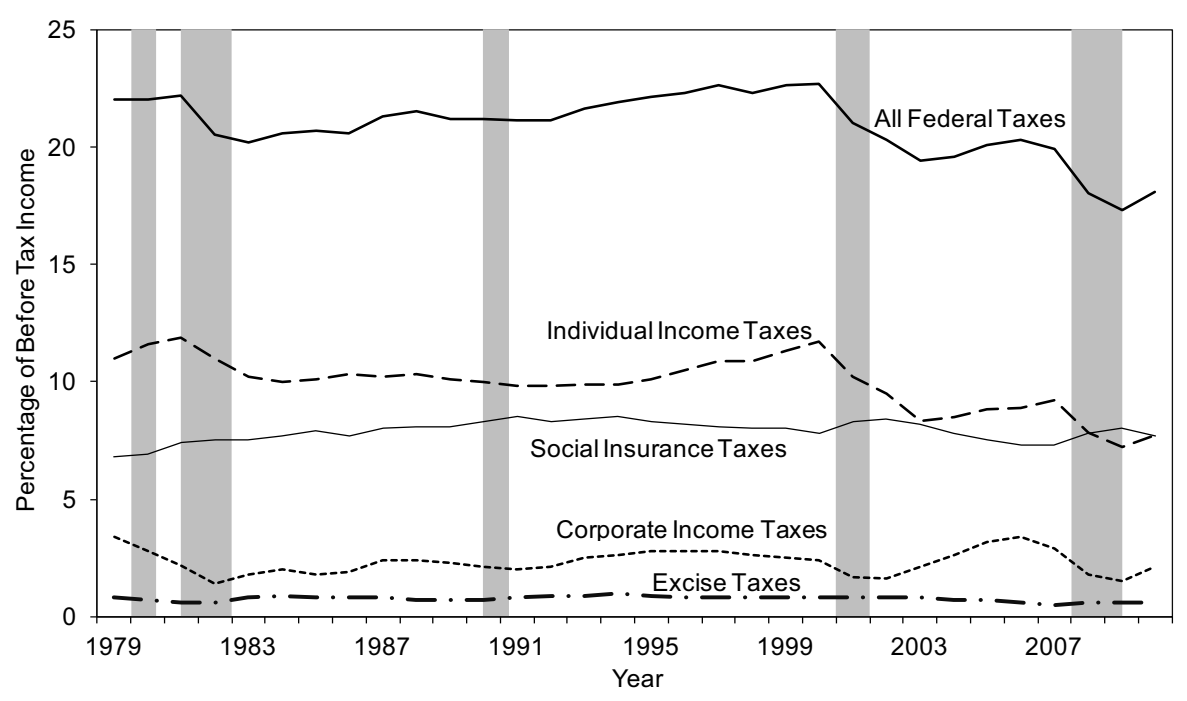

Fig. 7.8 Average tax rates for all households by tax source, 1979-2010

tions, coupled with the recession, reduced federal taxes as a share of GDP to post-WWII lows.

The composition of federal taxes changed notably over the period. The reduction in average rates has come about primarily because of reductions in average individual income taxes rates, which fell by over 3 percentage points over the period, while the average payroll tax rate rose by about a percentage point. By the end of the period, payroll taxes were about as large as individual income taxes. Those variations stemmed from a combination of legislative changes and economic developments.

The average individual income tax rate peaked at 12 percent of household income in 1981. The individual income tax rate then fell as the tax rate reduction enacted in 1981 took effect. The rate rose in the late 1990s because of legislation enacted in 1993 and because of rapidly rising incomes. After 2000, the rate fell as a result of the 2001 and 2003 tax reductions and the recession in 2001. The Economic Stimulus Act of 2008 (which provided a partially refundable payment to almost all taxpayers) and the American Recovery and Reinvestment Act (ARRA) of 2009 (which introduced new refundable income tax credits and expanded existing one) both reduced income taxes further in the late 2010s.

The increase in the payroll tax rate came about in the 1980s as a result of increases in the cap on earnings subject to the Social Security payroll tax and legislation enacted in 1983 that accelerated previously scheduled increases in the Social Security payroll tax rate. Subsequent legislation in the early 1990s first increased and then eliminated the cap on earnings subject 


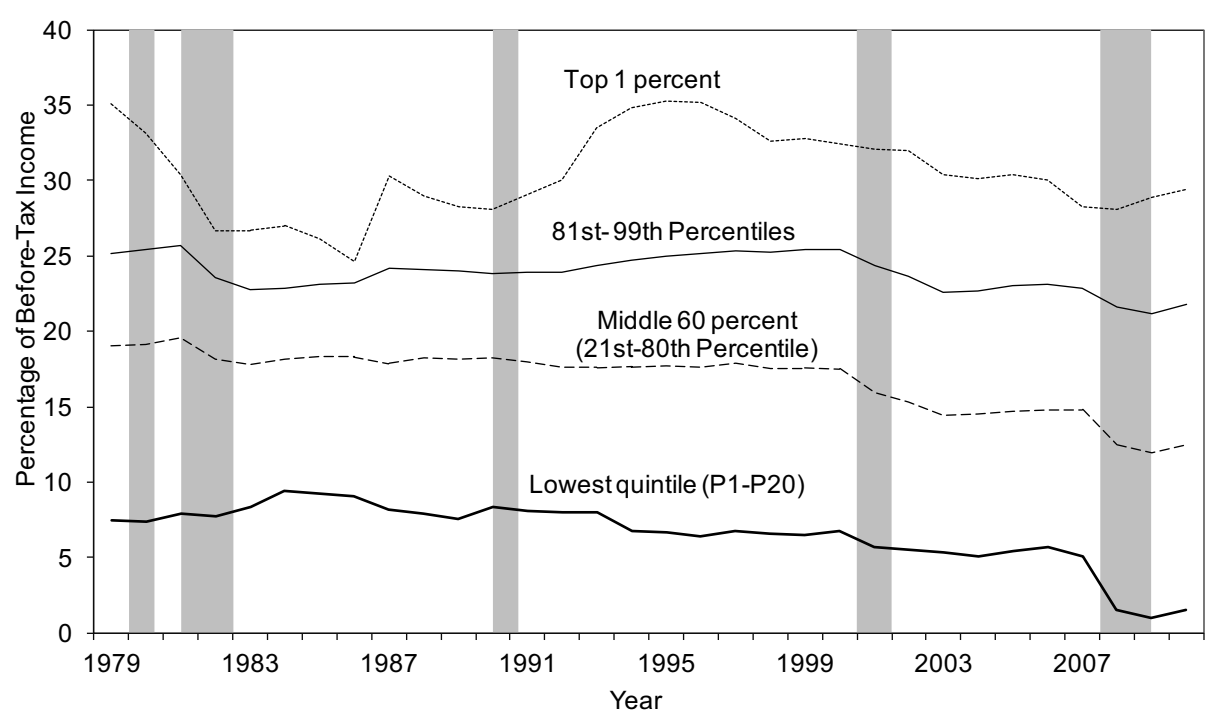

Fig. 7.9 Average federal tax rate by pretax income group, 1979-2010

to the hospital insurance payroll tax (which is used to finance a portion of Medicare). The payroll tax rate declined in the late 1990s and middle of the first decade of the twenty-first century as labor income grew more slowly than other income sources and as earnings above the Social Security taxable maximum grew more rapidly than earnings below the maximum. Those trends reversed around the recessions in 2001 and 2008 to 2009, pushing up average payroll tax rates.

Taken as a whole, the federal tax system is progressive - that is, average tax rates generally rise with income. In 2010, households in the bottom fifth of the before-tax income distribution paid 1.5 percent of their before-tax income in federal taxes, households in the middle quintile paid 11.5 percent, and households in the highest quintile paid 24.0 percent percentile (see figure 7.9). Average rates rose within the top quintile, and households in the top 1 percent of the before-tax income distribution faced an average rate of 29.4 percent while those in the 81 st to 99 th percentiles paid 21.8. Much of the progressivity of the federal tax system derives from the individual income tax, where average rates ranged from -9.2 percent for the bottom income quintile to 1.6 percent for the middle quintile, 13.8 percent for the highest quintile, and 20.1 percent for the top 1 percent. $^{12}$

For most income groups, the average federal tax rates in the 2008 to 2010 period were the lowest observed in the 1979 to 2010 period. The pattern in

12. A negative average rate occurs when refundable tax credits exceed the income taxes owed by an income group. 
the intervening years is more varied, reflecting the interaction of numerous changes to tax law and changes in the composition and distribution of income.

For the lowest income group, the average rate fell from 7.5 percent in 1979 to 1.5 percent in 2010. Almost two-thirds of that decline came between 2007 and 2009, largely as a result of new refundable tax credits introduced by the ARRA. The largest of those credits, the Making Work Pay credit, expired at the end of 2010. Declines in earlier years were mainly caused by increases in the earned income tax credit, especially in the 1990s. Payroll tax rates rose steadily for the lowest income group, offsetting some of the decline in their individual income tax rate.

Households in the middle three income quintiles saw their average tax rate fall by 6.6 percentage points over the thirty-two years studied, from 19.1 percent in 1979 to 12.5 percent in 2010 . That decline was due primarily to declines in individual income taxes. The average tax rate for this group fell somewhat in the early 1980s and then fluctuated within a fairly narrow band through the 1980s and 1990s. Over the 2001 to 2003 period, the rate declined by 3.1 percentage points, reflecting numerous changes in law enacted in 2001 - such as the expansion of the child tax credit, reductions in tax rates, and increases in the standard deduction for married couples - that lowered taxes for households in the middle quintiles. The rate fell 2.8 percentage points from 2007 to 2009, largely because of changes enacted in ARRA.

The average tax rate for households in the 81st to 99th percentiles of the income distribution also reached a low point in 2009, about 4 percentage points below its 1979 level, before rising slightly in 2010. That rate fell in the early 1980s and then crept up over the remaining part of that decade and the 1990s, such that by 2000 it slightly exceeded its 1979 level. The average tax rate for this group fell 2.9 percentage points between 2000 and 2003, rose modestly from 2003 to 2007 , and then fell another 1.7 percentage point from 2007 to 2009 , before rising 0.7 percentage points in 2010 .

In contrast, the average tax rate in 2010 for households in the top 1 percent of the before-tax income distribution was above its low point, reached in the early 1980s. The average tax rate for those households fell in the early 1980s and then rose following enactment of the Tax Reform Act of 1986. The average tax rate for that group then fell somewhat again in the latter half of the 1980s before climbing in the 1990s. That climb reflected changes in law that raised tax rates for that group as well as rapid increases in their income, which caused their average tax rate to rise as more income was taxed in higher tax brackets. Tax rates for households in the top percentile declined after 2000 . The decline was especially rapid in 2003, when a reduction in the tax rate for the top tax bracket enacted in 2001 took effect and further changes in law reduced tax rates on dividends and realized capital gains. The tax rate fell again in 2007 , mostly due to declines in corporate income taxes, and then rose somewhat from 2007 to 2009, as sharp declines 
in capital gains income caused a larger portion of the income of that group to be subject to the ordinary income tax rates. Their tax rate continued to rise in 2010 because of increased corporate income taxes, muted somewhat by declining individual income tax rates.

\section{Progressivity of Federal Taxes}

Because tax rates were lower for all income groups in 2007 than in 1979, it is not immediately apparent from examining tax rates alone whether combined federal taxes became more or less progressive over that period. To measure the level and change over time in the progressivity of taxes, researchers have developed various approaches to summarizing the distribution of taxes into a single number. One such measure, often called the Reynolds-Smolensky index, is simply the difference between the Gini for before-tax income and after-tax income. As seen earlier (figure 7.5), that measure was very stable over the thirty-two years studied. Federal taxes reduced the Gini coefficient by about 0.04 points at the beginning of that period. The redistributive effect of the tax system fell throughout the early 1980s, reaching a nadir of 0.023 points in 1986, then rose back to around 0.04 in the mid-1990s. From then on, it has varied within a very narrow range.

Another measure, the Kakwani index, is the difference between the tax concentration index, ranking households by their before-tax income, and the Gini index for before-tax income (Kakwani 1976). That index is effectively based on a comparison of shares of taxes paid with the share of income earned, and defines progressivity as the degree to which the former are more concentrated. Positive values indicate a progressive tax (shares of taxes are more skewed than shares of income) and a negative value indicates a regressive tax. An important property of that index is that it is unaffected by the size of the tax system. The Kakwani index is mathematically related to the Reynolds-Smolensky index. Specifically, the Reynolds-Smolensky index is equal to the Kakwani index multiplied by the average tax rate, plus a (usually small) term for reranking of households (Creedy 1999). The two indexes reflect different concepts of progressivity, and can move in different directions.

The Kakwani index for the tax system as a whole has increased somewhat over the period studied here (see figure 7.10). While pretax income has grown more skewed, the skewness of tax payments has increased even more. After an initial period of decline, that progressivity measure reached its 1979 level by 1994, and has continued to increase since then. The measure jumped notably in 2001 and 2008, in large part because of legislative action.

At the same time, the tax system grew smaller over the three decades studied here, as indicated by the average tax rate. That effect approximately netted out the increased concentration of tax payments, and produced a tax system that reduces inequality by about the same amount -0.04 Gini points - at the beginning and the end of the period. 


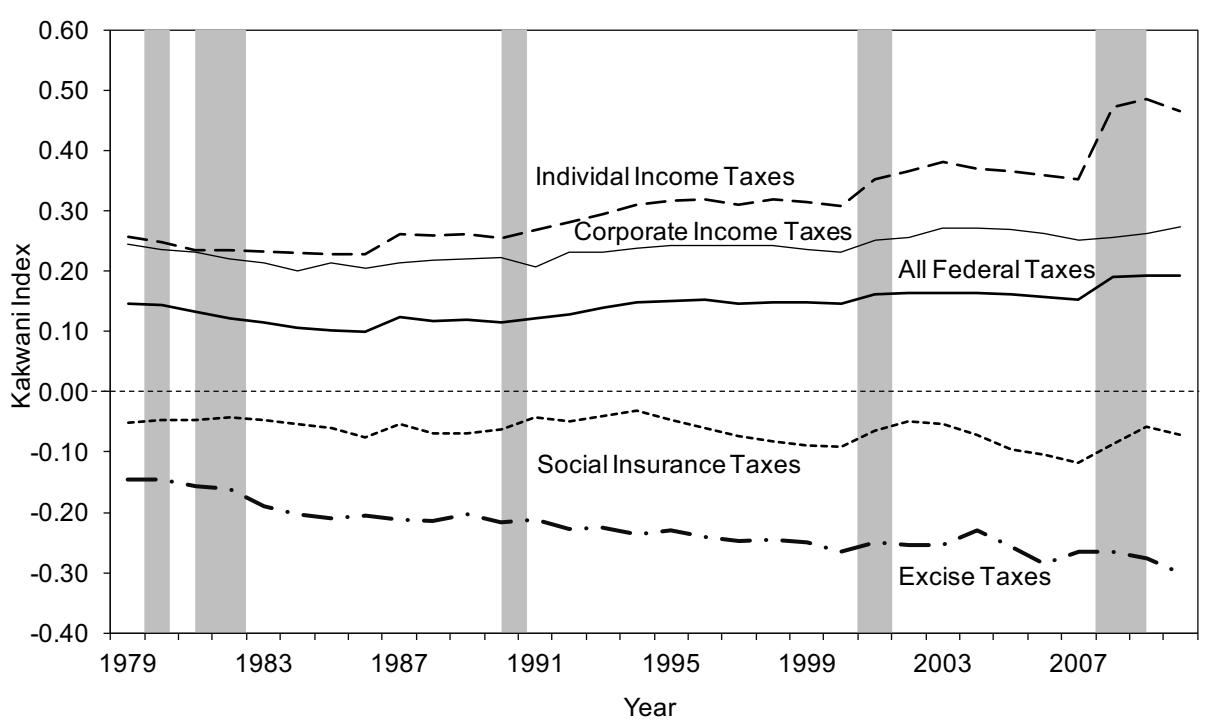

Fig. 7.10 Progressivity index by tax source, 1979-2010

\section{Progressivity of Federal Taxes by Source}

Another useful property of the Kakwani index is that it can be decomposed by tax source. The index for the entire tax system is equal to the average of the indexes for each source, weighted by the size of each tax source.

By that measure of tax concentration, individual income taxes are the most progressive source. Average federal income tax rates in 2010 ranged from -5.6 percent for households in the lowest income quintile to 18.8 percent for the 1 percent of the population with the highest income. The lowest income quintile has a negative average tax rate because, as a group, households in that quintile qualify for more in refundable tax credits than they owe in income taxes (before the credits are applied).

Those taxes became notably more progressive over the past twenty-nine years, particularly from 1990 through 1995 and again between 2000 and 2003 and finally post-2007. Tax law changes account for much of those periods of growth. The early 1990s saw increases in tax rates for higher income taxpayers, as well as large expansions of the earned income tax credit, which reduced taxes at the bottom of the income distribution. The first tax reductions enacted in the early twenty-first century also reduced taxes by more (relative to income) for lower income taxpayers. Finally, the changes enacted in ARRA provided bigger tax reductions relative to income in the lower portions of the income distribution.

Corporate income taxes are progressive, and have become more so. Those 
taxes are allocated in proportion to income from capital (75 percent) and labor (25 percent). Any change in the measured progressivity of those taxes simply indicates shifts in the underlying income distribution used to allocate the taxes, not structural features of the taxes themselves.

The Kakwani index for payroll is negative, indicating that those taxes are regressive. ${ }^{13}$ Average rates for payroll taxes are fairly flat across most of the income distribution but are lower at the top in part because more of the earnings for those households are above the maximum income subject to Social Security taxes and in part because earnings are a smaller share of their income. Payroll taxes have become more regressive largely because labor income (the base of the tax) for households at the bottom grew more rapidly than their other sources of income over the period, pushing up their payroll taxes. Legislated increases to the maximum taxable amount for hospital insurance payroll taxes in the early 1990s offset some of that decline.

Excise taxes are also regressive. Lower-income households tend to spend a large share of their income on such goods as gasoline, alcohol, and tobacco, which are subject to federal excise taxes. Excise taxes have grown more regressive over time. As incomes have increased among the highest-income taxpayers, their spending on excise-taxed goods has fallen as a share of income.

Taken together, the tax system as a whole became somewhat more progressive. While the progressivity of the individual income tax increased, that tax source also became less important. Payroll taxes, a slightly regressive tax source, grew in importance.

\subsection{Conclusions}

The distribution of after-tax income has grown more unequal over the thirty-two years covered in this analysis. Virtually all of that increase occurred because of a growing inequality in market income. The shift in market income, in turn, was primarily due to increases in inequality of various income sources, especially labor income, rather than a changing mix of income sources. Outside of the recent recession, the tax and transfer system did little to offset the growing inequality, reducing the income inequality by roughly constant amounts over most of the period. The transfer system became larger, but less targeted to the bottom of the income distribution. The tax system became smaller, but more concentrated at the top of the income distribution.

The transfer system did become more redistributive in the 2008 to 2010 period, but much of that effect reflects temporary growth in transfer programs, and we do not expect that to persist once the economy recovers. The

13. Although Social Security payroll taxes are not progressive, the program as a whole is generally thought to be progressive because the ratio of the lifetime benefits received from Social Security to the lifetime payroll taxes paid for the program is higher for people with lower lifetime earnings than for people with higher earnings. 
tax system also became more progressive in those years as average tax rates for lower-income households fell as the result of new refundable tax credits enacted during the recession and average tax rates for the high-income groups rose as the share of their income from dividends and capital gains, which are taxed at lower rates that other income, declined during the recession. We expect that some of those changes also will be temporary as a significant portion of the new refundable credits expired after 2010, and the share of income from dividends and capital gains for high-income households is likely to return to more normal levels.

\section{References}

Aguiar, M. A., and M. Bils. 2011. "Has Consumption Inequality Mirrored Income Inequality?" NBER Working Paper no. 16807, Cambridge, MA.

Armour, Philip, Richard V. Burkhauser, and Jeff Larrimore. 2013. "Levels and Trends in United States Income and Its Distribution: A Crosswalk from Market Income towards a Comprehensive Haig-Simons Income Apporach." NBER Working Paper No. 19110, Cambridge, MA, June.

Atkinson, A. B., T. Piketty, and E. Saez. 2011. "Top Incomes in the Long Run of History." Journal of Economic Literature 49 (1) 3-71.

Attanasio, O., E. Hurst, and L. Pistaferri. 2012. "The Evolution of Income, Consumption, and Leisure Inequality in the US, 1980-2010." NBER Working Paper no. 17982, Cambridge, MA.

Burkhauser, R. V., S. Feng, S. P. Jenkins, and J. Larrimore. 2008. "Estimating Trends in US Income Inequality Using the Current Population Survey: The Importance of Controlling for Censoring." NBER Working Paper no. 14247, Cambridge, MA.

Canberra Group. 2011. Handbook on Household Income Statistics, 2nd ed. United Nations Economic Commission for Europe. http://www.unece.org/index.php ?id=28894.

Chamberlain, A., and G. Prante. 2007. "Who Pays Taxes and Who Receives Government Spending? An Analysis of Federal, State, and Local Tax and Spending Distributions, 1991-2004." Working Paper 1, Tax Foundation, Washington, DC.

Cohen, M. L. 1991. "Statistical Matching and Microsimulation models." In Improving Information for Social Policy Decisions: The Use of Microsimulation Modeling, vol. II: Technical Papers, edited by Citro and Hanushek. Washington, DC: National Academy Press.

Congressional Budget Office (CBO). 2005. "Effective Tax Rates: Comparing Annual and Multiyear Measures." Report. Washington, DC: CBO. http://www.cbo.gov /publication/16212.

. 2011. "Trends in the Distribution of Household Income Between 1979 and 2007." Report. Washington, DC: CBO. http://www.cbo.gov/publication/42729. . 2012. "The Distribution of Household Income and Federal Taxes, 2008 and 2009.” Report. Washington, DC: CBO. http://www.cbo.gov/publication/43373.

Creedy, J. 1999. "Taxation Redistribution and Progressivity: An Introduction." Australian Economic Review 32 (4): 410-22.

D’Orazio, M., M. Di Zio, and M. Scanu. 2006. Statistical Matching: Theory and Practice. Hoboken, NJ: Wiley Press. 
DeNavas-Walt, C., B. D. Proctor, and J. C. Smith. 2010. "Income, Poverty, and Health Insurance Coverage in the United States: 2009, Current Population Reports, Series P60-238." Washington, DC: US Bureau of the Census.

Fei, J. C. H., G. Ranis, and S. Kuo. 1978. "Growth and the Family Distribution of Income by Factor Components." Quarterly Journal of Economics 92 (1): 17-53.

Gordon, R. J., and I. Dew-Becker. 2007. "Selected Issues in the Rise of Income Inequality." Brookings Papers on Economic Activity 2:169-90.

Institute on Taxation and Economic Policy (ITEP). 2009. "Who Pays? A Distributional Analysis of the Tax Systems in All 50 States." http://www.itep.org/whopays/.

Internal Revenue Service. 2012. "Statistics of Income-2010 Individual Income Tax Returns Publication 1304 and Earlier Years." http://www.irs.gov/uac/SOI-Tax -Stats-Individual-Income-Tax-Returns-Publication-1304-(Complete-Report).

Jones, A. F., Jr., and D. H. Weinberg. 2000. "The Changing Shape of the Nation's Income Distribution, 1974-1998." Current Population Reports, Series P60-204. US Bureau of the Census. http://www.census.gov/main/www/cprs.html.

Kakwani, N. 1976. "Measurement of Tax Progressivity, An International Comparison." Economic Journal 87 (345): 71-80.

Kopczuk, W., E. Saez, and J. Song. 2010. "Earnings Inequality and Mobility in the United States: Evidence from Social Security Data Since 1937.” Quarterly Journal of Economics 125 (1): 91-128.

Krueger, Dirk, and Fabrizio Perri. 2006. "Does Income Inequality Lead to Consumption Inequality? Evidence and Theory." Review of Economic Studies 73 (1): 163-93.

Lemieux, T. 2010. "What Do We Really Know About Changes in Wage Inequality?" In Labor in the New Economy, Studies in Income and Wealth, vol. 71, edited by Katharine G. Abraham, James R. Spletzer, and Michael J. Harper. Chicago: University of Chicago Press.

Lerman, R. I., and S. Yitzhaki. 1985. "Income Inequality Effect by Income Source: A New Approach and Applications to the United States." Review of Economics and Statistics 67:151-6.

OECD. 2008. "Growing Unequal? Income Distribution and Poverty in OECD Countries." Paris: Organisation for Economic Co-operation and Development.

Pechman, J. A. 1985. Who Paid the Taxes: 1966-85? Washington, DC: Brookings Institution.

Phares, D. 1980. Who Pays State and Local Taxes? Cambridge, MA: Oelgeschlager, Gunn, and Hain.

Piketty, T., and E. Saez. 2003. "Income Inequality in the United States, 1913-1998." Quarterly Journal of Economics 118 (1): 1-39.

Shorrocks, A. F. 1982. "Inequality Decomposition by Factor Components." Econometrica 50 (1): 193-211.

Slesnick, D. T. 2001. Consumption and Social Welfare: Living Standards and Their Distribution in the United States. Cambridge: Cambridge University Press.

Smeeding, T. M., and J. P. Thompson. 2010. "Recent Trends in the Distribution of Income: Labor, Wealth and More Complete Measures of Well Being." Working Paper, University of Massachusetts, June.

Wheaton, L. 2007. "Underreporting of Means-Tested Transfer Programs in the CPS and SIPP." 2007 Proceedings of the American Statistical Association, Social Statistics Section, Alexandria, Virginia. American Statistical Association. pp. 3622-9. 